\title{
POETIC VALUE AND EROTIC NORMS: A RESPONSE TO HELEN VENDLER
}

\author{
Vivian R. Pollak
}

How DOES POETRY mediate value? Helen Vendler asks this important question in her essay on Walt Whitman's four elegies for Abraham Lincoln: "Hush'd Be the Camps To-day," "O Captain! My Captain!" "When Lilacs Last in the Dooryard Bloom'd," and "This Dust Was Once the Man." Vendler notes that "the assassination of Lincoln of course provoked a flood of writing - journalistic, biographical, poetic," and that "of the many poems then written, Whitman's memorials have lasted the best" in public esteem. ${ }^{1}$ The concepts of longevity and public esteem are keys to her argument about poetry and value, and these ideals resonated for Whitman too. But Whitman also believed that "the real war will never get in the books," 2 and I will concentrate on describing some of the real — in the sense of consequential — wars that are elided by Vendler's idealizing analysis, which depends on certain foundational assumptions about lyric as a genre.

Professor Vendler observes that prose, whether spoken or written, enforces disciplinary values more emphatically than does poetry. She writes:

Most poetry mediates values differently from most prose. In prose, values are usually directly stated, illustrated, clarified, and repeated. One has only to think of the classical

Editor's Note:

Helen Vendler presented the Tanner Lecture on Human Values at the University of Michigan in October of 1999. Her lecture was called "Poetry and the Mediation of Value: Whitman on Lincoln" and was published in the Michigan Quarterly Review 39 (Winter 2000), 1-18. Arguing that lyric poetry needs "to find extremely compressed ways by which to convey value," Vendler offered readings of Whitman's four elegies for Lincoln and examined each poem's "use and critique of its own antecedent paradigms" in order to reveal "its own value-system" and to discover both its intelligibility and its originality.

The day after the lecture, a symposium was held at Michigan to discuss Vendler's approach to Whitman. Two of those responses-by Kenneth Fuchs and Mark E. Neely, Jr.- -were published in the same issue of the Michigan Quarterly Review. WWQR is pleased to publish a third response to Vendler's lecture, by Vivian R. Pollak, the author of The Erotic Whitman (University of California Press, 2000). Pollak's reply to Vendler was originally delivered at the Michigan symposium. 
form of the oration - and its descendants the sermon, the stump speech, and the university lecture - to see the importance placed, in an oral form, on reduplication of matter. Whitman's poetry retains many vestiges of the oration; and we can see such vestiges in "Lilacs." But most lyric poetry, being short, cannot avail itself of the ample terrain of oratory; it has consequently had to find extremely compressed ways by which to convey value. (2)

In her view, "Every lyric belongs to one or more anterior theoretical paradigms of genre," and readers of poetry need to understand the history of its forms (3). Citing the example of Moby Dick, Vendler observes that it includes no important female characters and that certain "effects and values are enabled by, and also prohibited by, this stratagem." Alternatively in lyric, she contends, "there is no such obvious norm" to guide the reader's imagination of what has been left out (2). Since norms imply a disciplinary structure and an ideological presence, lyric, as the less explicit genre, demands more of its readers than does prose. This argument begs the question of the relationship between obvious and occluded norms, but it implies that lyric poetry which is both popular and long lasting has effectively masked some or all of its immediate ideological goals.

Vendler, though, reminds us that Whitman's "poetic depended on a close connection, even an erotic one, with his imagined listeners" (4). What is the connection, I will ask, between lyric ideology and lyric eros? Whitman, I will suggest, was not interested in preserving the purity of lyric as a genre. For example, in a widely cited notebook entry, he expressed the desire to make words do "the male and female act." Here's what he says.

A perfect writer would make words sing, dance, kiss, do the male and female act, bear children, weep, bleed, rage, stab, steal, fire cannon, steer ships, sack cities, charge with cavalry or infantry, or do any thing, that man or woman or the natural powers can do. ${ }^{3}$

Whitman's catalogue of word-characters turns on "the male and female act," which exemplifies the power of nature. Ruefully, he acknowledges that he is an imperfect writer, since representation is imitation and since he is not God with a capital G, but rather only a lowercase creator. Whitman's notebook entry might seem to reinforce Professor Vendler's generic binary, but I think its meaning is more fluid. He accedes to some conventions of reading, which he associates with imperfection, but he also associates words and sexed bodies, both in this notebook entry and in his Leaves of Grass project. Whitman was both identified and disidentified with the phallicized body. In his catalogue of words, what begins with singing and dancing and kissing ends in weeping, bleeding, raging, stabbing and stealing. "The male and female act," the turning point in his narrative, has tragic public consequences. It is associated with the triumphal rhetoric of male militarism and, under the sign 
of socially sanctioned violence, normative sexuality is viewed as a form of private aggression. In Whitman's productively troubled imagination, a creation myth disintegrates into a song of war. His ambivalence about the language conventionally associated with "the male and female act" was at the heart of the heart of his project, leading him to challenge cultural conventions that stigmatized the body and suppressed its presence in "polite" literature.

Whitman identified himself as a lowercase creator and as an oppositional, antipatriarchal writer. He wanted to do everything in his power to turn words into characters and to endow them with sexual, emotional, and ideological potency, a potency he could then control. But the sex-project depended on a complicated series of ambivalences about intimate connections, literary and otherwise. "By my life-lumps!" he wrote in "Song of Myself," "becoming already a creator, / Putting myself here and now to the ambush'd womb of the shadows." "ambush'd"? Is the womb also an entrapper? Is the patriarchal sun his enemy? Do even shadows resist his advance? In directing our attention to his violations of a feminized nature and of naturalized conventions of language, Whitman suggests that forceful writing can be dangerous for both writer and reader. Even more explicitly, he likens it to rape. "I do not hurt you any more than is necessary for you," he famously promised. "I pour the stuff to start sons and daughters fit for These StatesI press with slow rude muscle, / I brace myself effectually-I listen to no entreaties." 5

Paradoxically, then, Whitman uses sexual metaphors to describe the radical transformations he seeks to effect through language. His metaphors are often extreme and he foregrounds the fictitiousness of his project. Some of his contemporaries missed the humor and it is easy to do so, especially when Whitman uses his own body as an emblem of power. With some consistency - for his attitudes toward gender and genre are remarkably heterogeneous-he sought to repress distinctions between body and soul, sex and culture, writer and reader. "You there, impotent, loose in the knees," he called, "Open your scarf"d chops till I blow grit within you, / Spread your palms and lift the flaps of your pockets, / I am not to be denied, I compel, I have stores plenty and to spare, / And any thing I have I bestow" ( $L G 74$ ). Will a perfect reader of Whitman absorb this passage uncritically? Does he ask us to forget conventions of reading that distinguish between physical and symbolic actions? Not really, but when we read Leaves of Grass, a book he referred to as his "daughter," Whitman encourages us to transgress generic ideals and the limiting conventions of authorship with which they are associated.

There is, too, an important sense in which his poetry is inseparable from his prose. One of the reasons we value Whitman today is because of his legacy as a writer of prose, which includes not only his early jour- 
nalism and fiction but more mature writings such as the Preface to the 1855 Leaves of Grass and the 1870 meditation on the problems and promise of America, the now widely cited Democratic Vistas. And then there is Specimen Days, containing Whitman's compelling eye-witness account of the war years, which was published in 1882, and which is full of "skips and jumps" and provocative "lackings and wants of connection." ${ }^{\prime 7}$ Furthermore, Whitman participated actively in writing the 1883 biography attributed solely to his friend, the Canadian psychiatrist Dr. Richard Maurice Bucke. ${ }^{8}$ By the time he died in 1892, Whitman had explained again and again how he wanted to be read. In the early years, he wrote anonymous reviews of his own poetry and engaged in other questionable publicity practices, such as taking a compliment from a private letter written to him by Ralph Waldo Emerson and using it on the spine of the 1856 Leaves of Grass. This appropriation created the impression that Emerson was endorsing the new book, which he wasn't, and it angered Emerson's friends. Some of Whitman's publicity maneuvers thus backfired, and he had a sizable group of enemies who considered him a fraud. When his war poems were reviewed in late 1865, there were people who attacked his patriotism, including the young Henry James, who felt that Whitman blew his own horn. (A more mature James recanted. $)^{9}$ Yet, in the face of adverse criticism and with great consistency, Whitman tried to create the audiences he felt he deserved, and on the fourteenth anniversary of Lincoln's assassination, Whitman delivered the first of a series of annual Lincoln lectures. He furnished members of the press with advance copies of his speech. ${ }^{10} \mathrm{I}$ don't mean to suggest that publishing prose prefaces and self-reviews and prose memoirs and critiques of American democracy insured Whitman's longevity and esteem as a lyric poet, but Whitman's prose project was surely one of the factors that made him somewhat comprehensible to sympathetic reviewers in his own time and in ours.

After offering a few brief comments about the provocative omissions of Professor Vendler's argument-omissions that in my view inhibit hybrid reading practices-I will return to her observation that "When Lilacs Last in the Dooryard Bloom'd" is the most "idiosyncratic" of Whitman's Lincoln elegies. What is the relationship, I will then ask, between gender, erotic idiosyncracy, self-revision, and what Vendler identifies as the courage of Whitman's untrammeled voice?

In praising "Lilacs," Vendler writes that "Whitman gives cosmic importance-rather than the political importance ascribed to it by historians - to Lincoln's death. The poem does not value facts; it does not value politics; it does not value Christianity; it does not value speaking in a voice other than one's own" (8). Many poststructuralist theorists, however, are deeply suspicious of the essentializing concept of voice. How do we know it? How do we recognize personal presence in poetry? How are voice and organicism and personal presence and Americanness 
related? Is cosmic importance related to Americanness? If so, is this a good thing? Do postcolonial theorists such as Edward Said and Gayatri Spivak and Homi K. Bhabha believe that this is the case? ${ }^{11}$ Do you? Do I?

Vendler's focus on the "aesthetic means" by which Whitman's poems take us "beyond the momentary topical excitement of Lincoln's death" (2) might seem to solve this problem, since she makes statements about poetry that are universalizing. I nevertheless assume that when she says "poetry" she means either poetry written in English or poetry that has influenced English-language poetry. Attacking "debased popular taste in poetry" and the literary values she attributes to soldiers and sailors and other members of Whitman's contemporary military audience, Vendler emphasizes that aside from the long and mournful journey of the coffin-train in "Lilacs," and "aside from the mentions of the mourning ceremonies attending the train at each of its stops, nothing in the poem depends on historical fact" (8). It seems to me that Vendler locates the experience of value within the head and heart of a reader who is presumed to be responding with a good deal of autonomy to a complete, compressed, and complex utterance. It also seems to me that she ignores the extent to which our experience of value in poetry is mediated through extrapoetic knowledge, including our knowledge of the author's biography.

Now it may be that even responsible biography is a form of fiction. As one who has recently wrestled with reconstructing a believable narrative about Whitman's sexual behavior, I would not deny that important mysteries remain. (And I'm not talking here about using myself as a character with a "moon-tan" and a hippie son or calling my hero "Dutch" Whitman. ${ }^{12}$ ) This said, I would like to suggest that many of us have been taught to value Whitman's poetry both for its supposed Americanness and for its radical revisions of conventional gender norms. Whitman himself was haunted by the relationship between these two projects. ${ }^{13}$ It is tempting to conclude that in "Lilacs" he solved this problem to his own satisfaction by representing himself not only as a bereaved citizen but also as a bereaved lover. Despite Whitman's claims to be treading in paths previously untrodden, in fact sentimental discourse encouraged verbal expressions of love between men. There already existed a politically evasive antebellum discourse of male-male love to which writers such as Emerson and Hawthorne and Melville were also responding. For example, when he was a third-year student at Harvard in 1820, Emerson sought to distinguish in his journal between "childish sentiment" and the more substantial "eye-fascination" inspired by another student, Martin Gay, who was a member of the freshman class. ${ }^{14}$ Whitman, in the sensational fiction he wrote in the $1840 \mathrm{~s}$, began to exploit the political and homoerotic potential of this "sentimental" subject, although he was not yet ready to claim it as his own. In the 1855, 
1856, and 1860 Leaves of Grass, the poet continued to exploit the politically subversive, cross-class implications of this "untamed" language. Leaves of Grass also absorbed widely shared anxieties about the immaturity of this discourse of male-male attraction. These anxieties were responsible in part for the compensatory hypermasculinity of some of the poet's poses. "No dainty dolce affettuoso I," he protested. ${ }^{15}$

By 1860, however, Whitman's sexually and politically unpredictable "rough" was beginning to submit to his own domestication. Whereas Whitman arrogantly revealed his underwear in the frontispiece to the 1855 Leaves of Grass, flaunting his body and his defiance of genteel decorum, in 1860 he dressed up for a truncated frontispiece portrait, concealing rather than pointing to his "live parts." In Drum-Taps and its "Sequel," he was even more reluctant to reinforce his outrageous, "queer person" image. ${ }^{16}$ Whitman's war opened with a resolution to cultivate a purified body. Following the attack on Fort Sumter, he wrote in his notebook: "I have this hour, this day resolv'd to inaugurate for myself a pure perfect, sweet, cleanblooded robust body by ignoring all drinks but water and pure milk - and all fat meats late suppers - a great bodya purged, cleansed, spiritualised invigorated body." 17 The stateliness we experience in "Lilacs" undoubtedly depends to some extent on the absence of the sexual exhibitionism we encounter in the earlier style. The erotic triangle created by the bereaved lover and Lincoln and "the dark mother always gliding near with soft feet" is, one feels, permanent. It has none of the vivid sexual "perturbations of Leaves of Grass."

Throughout Drum-Taps and its war-torn "Sequel," Whitman celebrates the love of comrades while de-eroticizing his language. Perhaps this is why he explained to his friend William Douglas O'Connor in January 1865, "Drum Taps has none of the perturbations of Leaves of Grass" and called Drum-Taps "more perfect as a work of art."18 In Whitman's private writings, "perturbation" is a uniquely resonant word. He used it in a notebook entry of July 1870, which has yielded up some of its mystery to biographical detection. Writing in an alphanumeric code, and erasing his references to a "he" so that "he" becomes "she," Whitman cautioned himself to give up his "UNDIGNIFIED PURSUIT of 164-too long, (much too long) persevered in; so humiliating." "It is IMPERATIVE, that I obviate \& remove myself ( \& my orbit) at all hazards, from this incessant enormous E abnormal PERTURBATION," he warned himself, continuing, "Depress the adhesive nature / It is in excess - making life a torment / Ah this diseased, feverish disproportionate adhesiveness." 19 "164" was Peter Doyle, an Irish immigrant and exConfederate soldier whom Whitman met during the winter of 18651866, when Whitman boarded a horse-drawn streetcar on which Pete, a workingman, was the conductor. For the better part of the next decade, Whitman and Pete formed a recognizable couple. They did not live together-Doyle lived with his mother and Whitman lived in a se- 
ries of uncomfortable rented rooms. (His government office had the gas fire and the good light and the view.) It seems that Whitman and Doyle were lovers but that Whitman's jealousy, and perhaps Doyle's, often betrayed them into destructive, or as Whitman viewed them, self-destructive actions.

The word "adhesive," as in "Depress the adhesive nature," was one that Whitman had adopted in the 1850s from the phrenologists. He used it in all three of his pre-war books, and it was part of a larger quest for a new, and more finely inflected, language of love. While Whitman continued to appropriate new words for what he called "the friendly sentiments," observing that such words were strangely absent in American literature while the passionate male-homoerotic relationships they were meant to describe were a commonplace fact of life, by 1865 there was too much public and private sadness for him to continue aggressively along these lines. ${ }^{20}$ The antebellum Whitman of the Calamus sequence had hoped that eroticized "affection" would "solve every one of the problems of freedom," but the war had proved him wrong. ${ }^{21}$

Whitman's war-chastened conception of a perfect art work is reflected in his 1865 letter to O'Connor, which was written in January and consequently before Lincoln's assassination. A perfect art work, he explained to O'Connor, who was his close friend, is not only emotionally passionate but formally controlled. "I am perhaps mainly satisfied with Drum-Taps," he wrote,

because it delivers my ambition of the task that has haunted me, namely, to express in a poem ( $\&$ in the way I like, which is not at all by directly stating it) the pending action of this Time $\mathcal{E}$ Land we swim in, with all their large conflicting fluctuations of despair \& hope, the shiftings, masses, \& the whirl \& deafening din, (yet over all, as by invisible hand, a definite purport \& idea) - with the unprecedented anguish of wounded \& suffering, the beautiful young men, in wholesale death \& agony, everything sometimes as if in blood color, \& dripping blood. The book is therefore unprecedently sad, (as these days are, are they not?) - but it also has the blast of the trumpet, $\&$ the drum pounds $\&$ whirrs in it, \& then an undertone of sweetest comradeship \& human love, threading its steady thread inside the chaos, \& heard at every lull $\&$ interstice thereof-truly also it has clear notes of faith $\&$ triumph. ${ }^{22}$

That undertone of sweetest comradeship and human love twines together a number of erotic triangles in "Lilacs"-most obviously lilac and star and bird, less obviously the thought of death and the knowledge of death and the poetic "I" in the middle, holding hands as with companions ( $L G 334$ ). But in his proud letter of January 1865 to William Douglas O'Connor, Whitman went on to add, strangely, that in Leaves of Grass he saw himself as having mapped out or thrown together "for American use, a gigantic embryo or skeleton of Personality." "I am satisfied with Leaves of Grass (by far the most of it)," he wrote, "as expressing what was intended, namely, to express by sharp-cut self as- 
sertion, One's-Self $\mathcal{E}$ also, or may be still more, to map out, to throw together for American use, a gigantic embryo or skeleton of Personality, fit for the West, for native models-but there are a few things I shall carefully eliminate in the next issue, \& a few more I shall considerably change." ${ }^{23}$ What was it he would need to eliminate for American use?

Well, for one thing, Whitman reconfigured "the problems of freedom" to eliminate the slavery crisis and allied problems of race. Skeletons, for example, figure prominently in "Lilacs," when in the poem's sweeping penultimate vision the bereaved lover sees the "white skeletons of young men" (336). But the Africanist presence that had been a source of wonder, "perturbation," and self-definition in the 1855, 1856, and 1860 Leaves of Grass virtually disappears from Drum-Taps and its "Sequel." "Lilacs" engages in a soothing but also dangerous coverup of the racialized ideologies that led to Lincoln's presidency and death, and it "covers over" the unresolved racial crisis of the post-war era as well. Following Lincoln's death, Whitman clarified and simplified his moral mission. The poet of the idiosyncratic, individualized, and racially marked body became the poet of the more abstract body collective. There are no African-Americans in the 1865-1866 book, and it was not until 1881 that the (from my perspective) appalling poem "Ethiopia Saluting the Colors," which features pidgin-English and a mammy so indistinct she is "hardly human" (LG 318-19), was incorporated into the Drum-Taps sequence. Whereas in 1855 Whitman had dramatized an encounter with a "runaway slave" who escapes North and had written "I am the hounded slave,"

\section{.... I wince at the bite of the dogs,}

Hell and despair are upon me .... crack and again crack the marksmen,

I clutch the rails of the fence .... my gore dribs thinned with the ooze of my skin,

I fall on the weeds and stones,

The riders spur their unwilling horses and haul close,

They taunt my dizzy ears . . . . they beat me violently over the head with their whipstocks $^{24}$

the war accelerated his swerve away from the ideological controversies associated with painful and beautiful fleshly particulars. Erotic omissions purified and whitened the erotic e-missions of the earlier books.

In the antebellum editions of Leaves of Grass, Whitman's outing of himself as a model of unconventional sexual desire had been incomplete. To stand between the slave and the slavemaster was also to stand between sexual identities and to refuse erotic extremes. His fear of "conflicting and irreconcilable interiors, and the lack of a common skeleton, knitting all close" 25 was even greater after Lincoln's death, and in 1867, Whitman eliminated three of the more personal Calamus poems from Leaves of Grass, engaging in an extraordinary feat of self-censorship that 
underscores his suspicion of a merely aesthetic, or self-gratifying performance. One of the poems he dropped was a favorite of the British sex reformer John Addington Symonds, who was puzzled to discover that Calamus 8 ("Long I thought that knowledge alone would suffice me") had disappeared from view. A meditation on value, this poem thrilled Symonds as a "trumpet-call," and in 1889, when he had been corresponding with Whitman for many years, he was eager to get the aging poet to commit himself to a modest version of homosexual rights. As part of this correspondence, Symonds wrote to ask, why "have you so consistently omitted this ["Long I thought that knowledge alone would suffice me"] in the canon of your works?" 26 Whitman never answered, but since the Calamus poems seek to lend public significance to homoerotic and homosexual attachments, Whitman was willing to omit poems and parts of poems that, with the advantage of hindsight, no longer seemed suitable for "American use."

In her focus on cosmic or collective or archetypal ritual, and on syntactic positioning, Vendler powerfully represses the specifically national dimension of Whitman's commanding value. Although she mentions his patriotism as a defining feature of the "first two memorials of Lincoln"- of "Hush'd Be the Camps To-day" and "O Captain! My Captain!"- and although she alludes to certain American features of Whitman's aesthetic topography in "Lilacs," in her view these panoramic features almost distract the poet from his visionary art of song (11). She suggests an inverse relationship between localized and generalized effects. The local is not ideal, the ideal is not local. ${ }^{27}$

In Vendler's reading, which is exquisitely sensitive to some effects but supremely indifferent to others, the 1871 poem "This Dust Was Once the Man" has less longevity and value than "Lilacs" in part because its Unionism is more obvious. She calls it a poem of "tortured syntax," and situates "the foulest crime in history known in any land or age" in the context of Lincoln's "historical greatness" (17). What is the foulest crime in history known in any land or age? Is it to enslave another, to destroy the Union, or to assassinate a perfect president? Vendler's formalist and broadly humanist reading of value admits questions about "what stance the American poet should adopt when speaking of important national events" (18), but it mainly focuses on repressing the particulars of Whitman's Americanness, of his racialized politics, and of his sexuality. The art of song she describes is less temporal than atemporal; its project is using history to transcend history. Value emerges as a consequence of this transcendence, which is not complicit with violence, political or otherwise. Whitman's great elegy subdues symbols, but Vendler is unconcerned with the relationship between subduing symbols and subduing races and minority cultures. The style of "Lilacs" she describes "gives cosmic importance-rather than the political importance ascribed to it by historians - to Lincoln's death" (8). 
There is dominance and submission, but in some way-miraculously? the style also values "showing over telling" (11), "free musical language" (13), and "the idiosyncratic voice" (15). It seems that no master narrative triumphs and that only syntax is tortured.

I nevertheless agree with Helen Vendler when she states, "The valuesystem of an original poet - and therefore of his or her poems-will be in part consonant with, in part in dispute with, the contemporary values of the society from which he, and they, issue. Were the poetry not intelligible with respect to those social values, it could not be read; were it not at a distance from them in some way, it would not be original" (4). For many readers, Whitman represents what it means to be an American original. $\mathrm{He}$ is a "rough," but not too rough. He "keeps as delicate around the bowels as around the head and heart," and he compliments himself on the fact that he does not "press [his] finger across [his] mouth," since he is

Walt Whitman, an American, one of the roughs, a kosmos,

Disorderly fleshy and sensual . . . . eating drinking and breeding,

No sentimentalist .... no stander above men and women or apart from them ....

no more modest than immodest. ${ }^{28}$

I have been quoting from Whitman's 1855 poem "Song of Myself." After the war, he added lines that ground his claim to poetic authority in fourth-generation nativism on both sides of his ancestry, telling us that he was "Born here of parents born here from parents the same, and their parents the same" (LG 29). Ironically, these lines were imported from the opening poem of the 1860 volume, the "Proto-Leaf" he subsequently renamed "Starting from Paumanok." Whitman also revised "Paumanok" to explain that he was not only "well-begotten" but raised by a "perfect mother" (15). For many influential readers, those who influence a poet's longevity and public esteem, that mother is America ${ }^{29}$ Notice, though, that Whitman's elaborate geography of selfauthorization starts from "Paumanok," "Paumanok" being a queer, dissonant Indian word for Long Island. This is not the homogeneous Long Island of the Walt Whitman Shopping Center in Huntington but a hybridized place, where a queer poet can reinvent his history and make it sound common and longlasting and true.

Walt Whitman was an intensely self-revising artist. In his practice, to be an American poet was to look to the future, to strike up for a New World. Yet as Professor Vendler reminds us, in "Lilacs" Whitman asks subtle and insistent questions about the relationship between the old and the new. She refers to the poem's use of Egyptian and Greek images and to the poet's preference for pre-Christian ways of imagining and ritualizing death to those offered by "the Christianity in which he had been raised" (12). More particularly, she refers to his hymn to a 
female deity, Death, in the second half of canto 14 as "the lyric center of 'Lilacs," and suggests that it is "therefore allied to the earliest lyrics we have, the Orphic hymns to abstractions such as Death and the Homeric hymns to gods and goddesses such as the maternal goddess Demeter, mother of the Persephone lost to Hades" (13). She further distinguishes this lyric center from the poem's "moral climax" in canto 15, in which the loving and thirsting eyed poet gazes on the white skeletons of young men. Establishing lovely correspondences between canto 15 and the Book of Revelation, Helen Vendler alludes to paradigms of the English elegy and to the "normality" of Egypt and Greece, but her sense of "the debris and debris of all the slain soldiers of the war" is informed neither by a racialized nor by a sexualized perspective. Recuperating this hybrid perspective will, I think, preserve "Lilacs" as an American poem for the future.

In attending to genres of reading as well as writing, we will honor great poets such as Whitman who provide us with what he calls in $A n$ American Primer "reborn words." ${ }^{30}$ Reborn words resist anxious sexualized and racialized reading practices; they refuse to reinscribe the exclusions of the past. At this time in the complex history of American reading, we need not choose between being readers of poetry and prose, between being fully autonomous or fully disembodied readers, nor between attending to totalizing and fragmentary concepts of omission. Whitman's style encourages us to honor the idiosyncratic - whether it be the shapely or grotesque particular. In doing so, we will come closest, I think, to suppressing the ideological fanaticism that in Whitman's view was the enemy, the devil in his book of life.

\section{Washington University in St. Louis}

\section{NOTES}

1 Helen Vendler, "Poetry and the Mediation of Value: Whitman on Lincoln," Michigan Quarterly Review 39 (Winter 2000), 2. Subsequent page numbers from this essay will be cited parenthetically in the text.

2 Specimen Days, in Walt Whitman: Complete Poetry and Collected Prose, ed. Justin Kaplan (New York: Literary Classics of the United States, 1982), 778.

3 An American Primer: With Facsimiles of the Original Manuscript, ed. Horace Traubel (Stevens Point, Wisconsin: Holy Cow! Press, 1987), 16.

4 Leaves of Grass: Comprehensive Reader's Edition, ed. Harold W. Blodgett and Sculley Bradley (New York: New York University Press, 1965), 76. Subsequent page numbers from this edition will be cited parenthetically in the text, preceded by " $L G$."

5 "A Woman Waits for Me," in Leaves of Grass: Facsimile Edition of the 1860 Text, (Ithaca: Cornell University Press, 1961), 303. 
6 The Correspondence, ed. Edwin Haviland Miller (New York: New York University Press, 1961-77), 1:247.

7 Specimen Days, 689.

8 See Richard Maurice Bucke, Walt Whitman (Philadelphia: David McKay, 1883).

9 Henry James, "Mr. Walt Whitman," Nation 1 (November 16, 1865), reprinted in Walt Whitman: The Contemporary Reviews, ed. Kenneth M. Price (New York: Cambridge University Press, 1996), 115-118. In 1903, when a literary friend indicated an interest in seeing the review, James responded in the strongest terms, disowning it as a "little atrocity ... . the gross impudence of youth." "Nothing would induce me to reveal the whereabouts of my disgrace," he continued, "which I only recollect as deep and damning." James's letter to Manton Marable is included in The American Essays of Henry Fames, ed. Leon Edel (Princeton: Princeton University Press, 1989), 131n.

10 See Jerome Loving, Walt Whitman: The Song of Himself (Berkeley: University of California Press, 1999), 388-389, and passim. He concluded these lectures with a reading of "O Captain! My Captain!"

11 See, for example, Edward Said, Orientalism (London: Routledge, 1978); Gayatri Chakravorty Spivak, "Scattered Speculations on the Question of Value," in The Spivak Reader, ed. Donna Landry and Gerald MacLean (London: Routledge, 1996), 107140; Homi K. Bhabha, "DissemiNation: Time, Narrative, and the Margins of the Modern Nation," Nation and Narration (London: Routledge, 1990), 291-322.

12 See Edmund Morris, Dutch: A Memoir of Ronald Reagan (New York: Random House, 1999).

13 For a fuller discussion of this topic, see Vivian R. Pollak, The Erotic Whitman (Berkeley: University of California Press, 2000), Chapter 5, "The Politics of Love in the 1860 Leaves of Grass."

14 See Gay Wilson Allen, Waldo Emerson (New York: Penguin Books, 1981), 52-53, 61, and E. Anthony Rotundo, "Youth and Male Intimacy," in American Manhood: Transformations in Masculinity from the Revolution to the Modern Era (New York: Basic Books, 1993), 56-91. See also Donald Yacovone, "Abolitionists and the 'Language of Fraternal Love" in Meanings for Manhood: Constructions of Masculinity in Victorian America, ed. Mark C. Carnes and Clyde Griffen (Chicago: University of Chicago Press, 1990), 85-95.

15 Leaves of Grass: Facsimile Edition of the 1860 Text, 20.

16 Correspondence, 1:4.

17 Notebooks and Unpublished Prose Manuscripts, ed. Edward F. Grier (New York: New York University Press, 1984), 1:438. The entry is dated "Thursday, April 18. 61."

18 Whitman, Correspondence, 1:247, 246.

19 Whitman, NUPM, 2:888-890.

20 On "the friendly sentiments," see An American Primer, 15.

21 Whitman, Leaves of Grass: Facsimile Edition of the 1860 Text, 349.

22 Correspondence, 1:246-247.

23 Correspondence, 1:247. 
24 Leaves of Grass: The First (1855) Edition, ed. Malcolm Cowley (New York: Viking, 1959), 62.

25 Democratic Vistas, in Walt Whitman: Complete Poetry and Collected Prose, 935.

26 The Letters of fohn Addington Symonds, ed. Herbert M. Schueller and Robert L. Peters (Detroit: Wayne State University Press, 1969), 3:425.

27 For an earlier version of this argument, see Helen Vendler, "Whitman's 'When Lilacs Last in the Dooryard Bloom'd," in Textual Analysis: Some Readers Reading, ed. Mary Ann Caws (New York: Modern Language Association, 1986), 132-143. This essay is more highly nuanced and more effective in placing "Lilacs" in the larger frame of Whitman's career.

28 Whitman, Leaves of Grass: The First (1855) Edition, 48.

29 For more on Whitman's reception as a specifically national poet, see Timothy Morris, Becoming Canonical in American Poetry (Urbana: University of Illinois Press, 1995), 27-53. Morris describes a process of individuation in canonmaking criticism that valued idiosyncrasy and unlikeness to other texts.

30 Whitman, An American Primer, 4. 